\title{
USING QUESTIONS BOX IN TEACHING SIMPLE PAST TENSE
}

\author{
Shanty Halim \\ shantynurul@yahoo.com \\ Politeknik Negeri Ujung Pandang
}

\begin{abstract}
This research is aimed at finding out to find out whether the use of questions box effective in teaching simple past or not. This research used pre-experimental method. Furthermore, this research was conducted at Politeknik Negeri Ujung Pandang. There were 20 students as sample. The findings of this research show that using questions box is effective in teaching simple past tense. It was proven by the significant difference between the students' mean score in pretest and posttest when used SPSS program. There was significant different ability of the students before giving treatment and after giving treatment. In the pretest, the mean score of the students pretest was 2.32 and the mean score of posttest was 7.52. Standard deviation of pretest was 1.42 and the standard deviation of posttest was 0.75 . The researcher also found that the students have positive interest toward the use of questions box in teaching simple past tense at Politeknik Negeri Ujung Pandang.
\end{abstract}

Keywords: teaching simple past tense, questions box, pre-experimental research

\begin{abstract}
Abstrak
Penelitian ini bertujuan mengetahui efektivitas penggunaan metode question box dalam pengajaran simple past tense. Penelitian ini menerapkan metode preeksperimental, yang dilakukan di Politknik Negeri Ujung Pandang dengan melibatkan 20 mahasiswa sebagai sampel. Hasil temuan penelitian ini membuktikan bahwa metode question box efektif digunakan dalam pengajaran materi simple past tense. Hal tersebut dibuktikan dari perbedan yang signifikan antara nilai pretest dan posttest yang dilakukan sebelum dan sesudah treatment. Pada pretest, nilai rata-rata siswa 2.32 dan nilai rata-rata pada posttest adalah 7.25, dengan standar deviasi sebesar 0.75. Peneliti juga menemukan bahwa mahasiswa menanggapi positif penggunaan metode question box dalam pengajaran simple past tense di Politeknik Negeri Ujung Pandang.
\end{abstract}

Kata kunci: pengajaran simple past tense, questions box, pre-eksperimental

\section{Introduction}

The knowledge of grammar is one of the important factors that students' should master in order to be able to listen, speak, read, and write correctly. Grammar needed to have a mastery of four basic language skills. Understanding grammar can put students' more in control of their language and help students' become effective 
when they speak, write, and even read. The communication needs of students will require that their language conform more closely to the rules of English grammar is used by native speaker. Grammar covers tenses, words order, modals, preposition, and adjective and other structure items. There are 16 tenses in English. One of tenses is Simple Past. Simple Past is a grammatical tense that places and action or situation in the past. Many English learners get difficult in learning simple past tense. One of the difficulties is the wrong usage of the verb.

Based on the description above, the researcher makes a media as the way they can ask their questions, it is called questions box. Questions box is a media that is made to solve the students' problem in simple past. By using questions box the students who have problems in grammar can ask without feeling shy because they just need to write the questions then put into the box. Coghill and Magendanz (2003:16) states that the grammar of a language is the set of rules that govern its structure. Grammar determines how words are arranged to form meaningful units. According to Swan $(2005: 19)$ states that grammar the rules that show how words are combined, arranged or changed to show certain kinds of meaning. Barket in Supraba (2012:6) states that grammar is the system of a language. People sometimes describe grammar as the rules of a language, but in fact no language has rules. If we use the word rules, we suggest that somebody created the rules first and then spoke the language, like a new game. But languages did not start like that. Languages started by people making sounds which evolved into words, phrases and sentences. All languages change over time. What we call grammar is simply a reflection of a language at a particular time.

Webster's pocket dictionary (2002:215) states that grammar is the structure of language; the rules for use of a language. In Oxford Dictionary (2005: 187), Grammar is rules for forming words in making sentences. In Oxford Advanced Learner's Dictionary (1995:517), Grammar is the rules in a language for changing the form of words and combining them into sentences. Collins (1990:20) tense is the verb form which shows whether you are referring to the past, present, or future. While, Harianto, et al (2003:230) tense is the change of verb forming in a sentence that causes of the change of time or adverb of time. Hornby (1978:891) states tense is verb form that shows time the present, past and future. Furthermore, Oxford 
learner's pocket dictionary (2012:7) states that tense is verb form that shows the time of the action; the present/past/future.

Wren et al (2012:78) tense a verb that refers to present time, time and future time. Based on the definitions above, the researcher concludes that tenses is a verb form or form of time to indicate the time of the action happened. Eastwood (2008:59) states that simple is use for an action in the past and can also refers to a series of action in the past. Azar (2002:27) states that the simple past indicates that an activity began and ended at a particular time in the past. Furthermore, Azar (2003:32) states that simple past is form ends in- ed for regular verbs.

The technical of term of media come from "Latin" language the plural form of "medium". Teaching media is all things that can be channel about information from the source of information to information receiving. The technical term of media is very popular in communication sector. Study and teaching process also as communication process. So, the media that we use in teaching is reaching media. Which, teaching media is all thing that use to give message. Media is all the form $\mathrm{f}$ utilize to process of information channeling. (AECT in Tira, 2012:17). According to Gerlach and Donald Elly (1980:241), media or medium is any person, material or event that establishes condition which enable learners or student to acquire knowledge, skill and attitudes.

Media is something, which can give message and can stimulate the brain of students, their feelings and their desire. (Asnawir and Usman, 2002:11). Based on definition above, the writer concludes that media is one of the teaching system component that can be used by the teacher as the tools to help the teaching and learning process. There are many kinds of teaching media from the simple and chip thing until the modern media and expensive.

Asnawir and Usman (2002:29) classified media into four types they are: (1) visual, for examples: film, strip, micro projector, blackboard, photograph and picture. (2) Audio Visual, for examples: video, film and TV. (3) Dramatize, for examples: Role-play, sosiodrama and pantomime. (4) Audio, for example: Recorder, electronic and radio.

Gerlach and Donald Elly (1980:297) classify media in six general categories: (1) Picture, Picture consist of photographs of any object or event, which 
may be larger or smaller than the object or event it represents. (2) Audio recording. Recording is made on discs, motion picture and soundtrack. These are reproduction of actual event or soundtrack (3) Motion picture. Motion picture is a moving image in color or black and white produced from live action or from graphic representation. (4) Television. This category includes all types of audio video electronic distribution system; which eventually appear on television monitor. (5) Real things, Simulation and Model. This category includes people, events, objects and imitation of real things. Imitation of real things can be used as a substitution for the actual object or events. Simulations is the replication of real situation, which has been designed to be as near the actual event or process as possible. Many media including the computers, tape recordings and motions pictures can be used for simulation. A model is replication or representation of reality. It is often in scale and may be miniature, exact size or an enlargement. (6) Program and computerassisted instruction. Program are sequences of information (verbal, visual or audio) which are designed to elicit predetermined responses. The most common examples are programmed text books or instructional programs prepared for computers. From the explanation above we can concludes that media is available in many kinds, they are visual, audio visual, dramatize, audio.

Asnawir and Usman (2002:14) give a brief explanation about the function of media, they are: (1) Media can overcome classroom. So, teaching process become more clear and interesting. (2) Media can make the direct interaction between students and environment. (3) Media can result variety observation. (4) Efficiency in time and energy. (5) Media can implant the right basic concept, real and realia. (6) Media can improve the quality of students in learning. (7) Media can give integral experience from the concrete to the abstract think. (8) Learning process be more interactive. Based on the explanation about the function of media above the writer concludes that media in teaching process is to make the quality of teaching and learning process become more effective and interactive.

Question is sentence, phrase, etc. that asks for information. Box is container made of wood, cardboard, etc. usually with a lid, used for holding solid things. So that, questions box is the box that is filled by questions. Questions box is a media as the way student can ask their questions. By this way, the students who have 
problems about simple past tense can ask without feeling shy because they just need to write the questions then put into the box and the questions answered by their teachers.

The usage of this way is expected to be able to solve the students' problems and to increase the students' desire in asking their questions. So that, it can improve their English. There are some steps in using questions box as follows: (1) Preparing a box as the media in gathering questions. (2) Teaching in the classroom. (3) Telling students to ask some questions. (4) Using questions box to gather the questions of the students who are shy to ask their questions directly.

\section{Research Method}

In this research, the researcher applied a pre-experimental method and it was conducted in eight meetings. This research consists of pre-test, treatment, and posttest. Pre-test was held before treatment and post-test was held after treatment.

This research was conducted at Politeknik Negeri Ujung Pandang. There were 20 students as sample. The instrument of the research used multiple choice and completion. It aimed at finding out the students' ability in using simple past tense.

\section{Findings and Discussion}

In this part the researcher presents about finding or the result of the pretest and the posttest of writing test. To know further about the result of data analysis, we can refer to the following tables.

The real score of students in pretest and posttest

\begin{tabular}{cccc}
\hline No & Name & Pre-Test & Post-test \\
\hline 1 & MA & 0.5 & 7 \\
2 & WI & 4.5 & 9 \\
3 & IS & 1 & 7 \\
4 & DA & 1.5 & 7 \\
5 & JU & 5 & 7 \\
6 & PI & 5 & 7 \\
7 & HA & 2 & 8.5 \\
8 & NU & 4 & 9 \\
9 & MU & 2 & 7 \\
\hline
\end{tabular}




\begin{tabular}{lccc}
\hline 10 & SY & 1 & 7.5 \\
11 & WO & 1.5 & 7 \\
12 & WA & 2 & 8 \\
13 & SI & 2 & 7.5 \\
14 & AD & 1.5 & 7 \\
15 & RE & 4.5 & 9 \\
16 & NU & 1 & 7.5 \\
17 & RE & 2 & 7 \\
18 & AT & 2 & 7 \\
19 & AD & 1.5 & 7.5 \\
20 & MR & 2 & 7 \\
\hline
\end{tabular}

After calculating the result of the students' pretest, the mean score and standard deviation of both groups are presented as follows:

\begin{tabular}{ccc}
\hline Type of Test & Mean Score & Standard deviation \\
\hline Pretest & 2.32 & 1.42 \\
Posttest & 7.52 & 0.75 \\
\hline
\end{tabular}

The data shows the mean score of the students pretest was 2.32 and the mean score of posttest was 7.52. Standard deviation of pretest was 1.42 and the standard deviation of posttest was 0.75 . It means that using questions box is effective in teaching simple past tense. Based on the students' result of pretest we can see that the students' ability in using simple past tense is still low.

The hypothesis were tested by using inferential statistic. In this case, the researcher used t-test (testing of significance) for faired sample t-test, which is a test to know the significance difference between the result of students' mean score in pretest and posttest. Assuming that the level of significance $(\alpha)=0.05$, the only thing which is needed, the degree of freedom $(\mathrm{df})=\mathrm{N}-1$, where $\mathrm{N}=19$, that the $\mathrm{t}-$ test is presented as follows:

The t-test students' achievement

\begin{tabular}{ccc}
\hline Variable & P-Value & $\alpha$ \\
\hline $\mathrm{X} 2-\mathrm{X} 1$ & .000 & 0.05 \\
\hline
\end{tabular}


Based on the analysis of the result above, it can be observed that the scores of students who have been taught the present continuous tense is more effective. The table above indicated that the result of $\mathrm{p}=.000$ while $\alpha=0.05$. It could be concluded that $\alpha$ was higher than $\mathrm{p}$. Therefore, the alternative hypothesis $\left(H_{1}\right)$ was accepted and null hypothesis $\left(H_{0}\right)$ was rejected.

From the analysis, the researcher concluded that there was a significant difference between pretest and posttest in improving through using questions box in teaching simple past tense. In other words, using questions box in teaching simple past tense could be used to increase the students' ability. The result of statistical analysis for level of significance $(\mathrm{p}=0.05)$ with degree of freedom $(\mathrm{df})=\mathrm{N}-1$, where $\mathrm{N}=19$. The probability value was smaller than $\alpha(0.00<0.05)$. It indicated that the alternative hypothesis (H1) was accepted and the null hypothesis (H0) was rejected. It means that using questions box is effective in teaching simple past tense.

The researcher conducted a researcher in teaching simple past tense by using a media, that media is questions box. Questions box is one of media that can be used as the way student can ask their questions. By this way, the students who have problems about their lesson especially simple past tense in this research can ask without feeling shy because they just need to write the questions then put into the box and the questions answered by their teachers. The data in findings has proved the researcher expectation in make questions box to solve the problems of students who lack of self confidence in questioning is succeed. The data shows that using questions box in teaching simple past is effective. It was shown by the significant difference between pretest and posttest in findings. The findings shows that the mean score in pretest 2.32 while the mean score in posttest 7.52 .

The comparison score between pretest and posttest result shows that no one got excellent category, very good category, good category, fairly good and fairly category. In other component, there were 3 students (15\%) got poor category, 17 students $(85 \%)$ got fairly poor category. In the posttest there was significant increasing of students' score. No one got very poor category, poor category, and fair category. In other component, there were 3 students $(15 \%)$ got very good category, there were 2 students (10\%) got good, there were 15 students $(75 \%)$ got fairly good. It implies that the students' comprehension of simple past tense was 
improved after giving treatment. Thereby, the description of the data in findings shows that there is significant difference between the students score in pretest and posttest. It can be shown in the next chart:

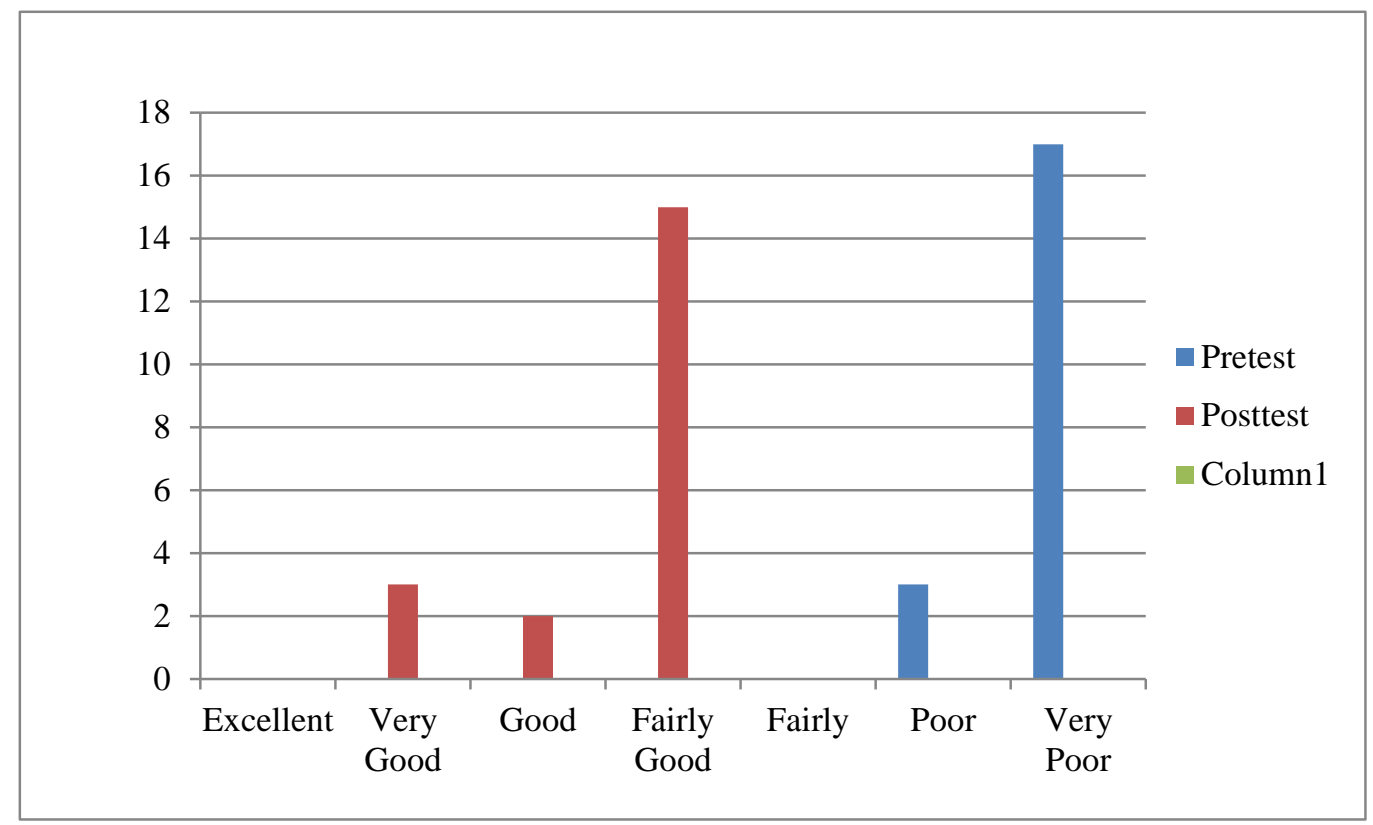

Based on the result of data analysis, the researcher found out that the use of questions box is effective in teaching simple past tense at the first year students of Politeknik Negeri Ujung Pandang.

\section{Conclusion}

Based on the result of data analysis, the researcher found out that the use of questions box is effective in teaching simple past tense at the first year students of Politeknik Negeri Ujung Pandang. Based on the analysis of the result, it can be observed that the scores of students who have been taught the simple past tense is effective. The Result of $p=.000$ while $\alpha=0.05$. It could be concluded that $\alpha$ was higher than $\mathrm{p}$. Therefore, the alternative hypothesis $\left(H_{1}\right)$ was accepted and null hypothesis $\left(H_{0}\right)$ was rejected. Furthermore, using questions box in teaching simple past tense can help the students to learn tenses easily.

\section{References}

Nina, A. R. (2010). Hafalan Luar Kepala 16 Tenses. Jakarta: PT. Buku Kita.

Asnawir \& Usman, B. M. (2002). Media Pembelajaran. Jakarta: Ciputat Pers. 


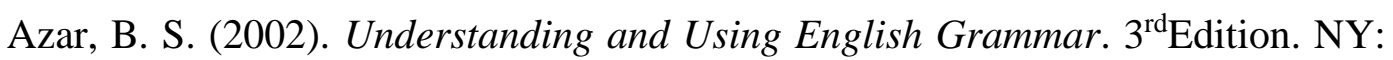
Pearson Education.

Azar, B. S. (2003). Fundamental of English Grammar. $3^{\text {rd }}$ Edition. NY: Pearson Education.

Best, J.W. (1997). Research in Education. $3^{\text {rd }}$ Edition. NJ: Englewood Cliffs.

Coghil, J. \& Magendanz, S. (2003). (Online).

http://www.englishindo.com/2011/04/definisi-grammar-menurut-ahli

grammar.html accessed on March 9 ${ }^{\text {th }}, 2016$ at 10.38 p.m.

Collins. (1990). English Grammar. $1^{\text {st Edition }}$. Birmingham University International Language. London.

Eastwood, J. (2008). Oxford Learner's Pocket Grammar. Oxfords, NY: Oxford University Press.

Gay, L. R., Mills \& Airasian, (2006). Educational Research: Competencies for Analysis and Applications. $8^{\text {th }}$ Edition. NJ: Pearson Education. Inc.

Gay, L. R. (1981). Educational Research: Competencies for Analysis and Applications. $2^{\text {nd }}$ Edition. Florida International University: Charles E. Merryl Publishing.

Gerlach, V. S., \& Elly, P. D. (1980). Teaching and Media: A Systematic Approach. New Jersey: Prentice Hall.

Hariyanto, D. (2003). English Grammar for General Application. $1^{\text {st }}$ Edition. Surabaya: Gitamedia Press.

Hornby. (1995). Oxford Advanced Learner's Dictionary. $5^{\text {th }}$ Edition. New York: Oxford University Press.

Mourssi, A. (2013). Which is Learnt First Regular or Irregular Simple Past Forms? A Quantitative Study in the Context of the Undergraduate Arab Learners of English (ALEs) under Two Different Teaching Methods. British Journal of Education, Society \& Behavioural Science, 3(3). pp. 265-281.

Pardiyono. (2006). Communicative Teaching 12 Tenses Grammar Materials. $2^{\text {nd }}$ Edition. Yogyakarta: C.V Andi Offset.

Rahman, A. F. A. (2010). English Grammar Completed Edition. $1^{\text {st }}$ Edition. Yogyakarta: Pustaka Widyatama

Romadhona \& Setyorini. (2002). Easiest Way to Master Tenses 16. Penerbit Victory. 
Halim: Using Question Box

Swan, M. (2005). Practical English Usage. $3^{\text {rd }}$ Edition. Oxford: Oxford University Press.

Thomson \& Martinet. (1986). A Practical English Grammar. $4^{\text {th }}$ Edition. New York: Oxford University Press.

Websters's Pocket Dictionary. (2002). Trident Press International.

Wren. (2012). High School English Grammar and Composition. $1^{\text {st }}$ Edition. New Delhi, India. 